\title{
Survival of the fittest: a comparison of medicine and health on Lord Howe Island and St Kilda
}

\author{
P Stride \\ Physician, Redcliffe Hospital, Redcliffe, Queensland, Australia
}

ABSTRACT Lord Howe Island and the St Kilda archipelago have many similarities, yet their communities had totally disparate outcomes. The characteristics of the two islands are compared and contrasted, and it is hypothesised that the differences in health and diseases largely explain the success of one society and the failure of the other.

KEYWORDS Infectious diseases, Lord Howe Island, neonatal tetanus, remote islands, St Kilda

Correspondence to $\mathbf{P}$ Stride, Redcliffe Hospital, Locked Bag I, Redcliffe, Queensland, Australia 4020

tel. +61732567980

e-mail

peter_stride@health.qld.gov.au

DECLARATION OF INTERESTS No conflict of interests declared.

\section{INTRODUCTION}

Oceanic islands are often isolated, and their history, economy and society are inevitably linked to the degree of contact with the outside world and the manner in which that contact takes place.'

The fortunate traveller who has visited both Lord Howe Island in the Pacific Ocean and the island archipelago of $\mathrm{St}$ Kilda in the Outer Hebrides will be struck by the many common features of these two remote islands; yet today one is a thriving society and the other was evacuated as a non-sustainable society in 1930. This paper analyses medical provision, health and outcomes on both islands in the period from 1788 when Lord Howe Island was discovered to 1930 when St Kilda was evacuated.

\section{GEOGRAPHY AND CLIMATE}

Both islands are remote even today (Figure I). Although the distance from Glasgow to St Kilda (main island, Hirta) is only some $340 \mathrm{~km}$ as the crow flies, it can take three or four days to get there using sea, land and air transport, including a landing on the 'airstrip' at Barra the beach at low tide. The journey from Brisbane to Lord Howe Island, a distance of $740 \mathrm{~km}$, in the past took several days by sea, but now a return flight is possible in one day. Both islands are small and have sheer cliffs and high rainfall. Both have UNESCO World Heritage status in which ornithological significance plays a large part, an abundant supply of fish in the surrounding sea and a nearby sea stack renowned for unique bird life. The difference in latitude and ambient temperature (Table I) were significant factors in the success of one society and the failure of the other.

\section{HISTORY AND OCCUPATION}

The Scottish islands have been inhabited for millennia and some have 5,000-year-old archaeological ruins that predate the pyramids of Egypt. St Kilda itself has
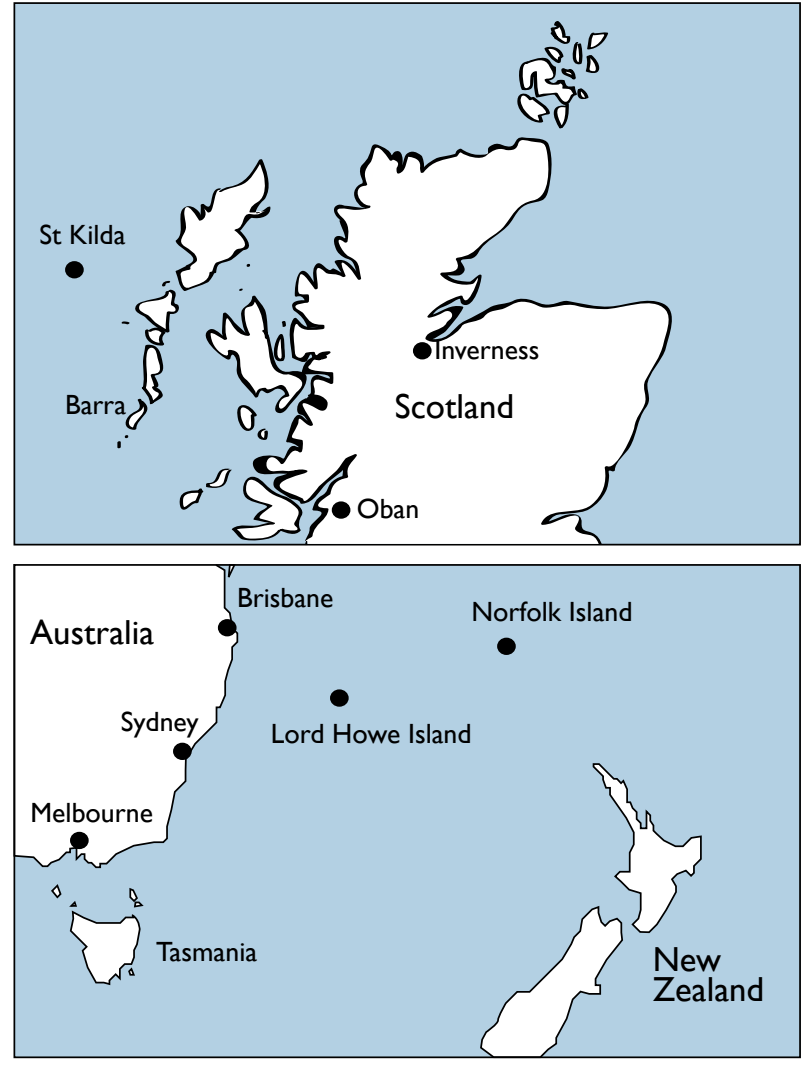

FIGURE I Locations of St Kilda and Lord Howe Island.

TABLE I A comparison of St Kilda and Lord Howe Island

\begin{tabular}{|l|l|l|}
\hline Feature & Lord Howe Island & St Kilda \\
\hline Land area $\left(\mathrm{km}^{2}\right)$ & $\mathrm{II} .76$ & 8.5 (Hirta only) \\
\hline $\begin{array}{l}\text { UNESCO World } \\
\text { Heritage listing }\end{array}$ & $\begin{array}{l}1982 \text { for beauty } \\
\text { and biodiversity }\end{array}$ & $\begin{array}{l}\text { I986 for cultural } \\
\text { and natural } \\
\text { significance }\end{array}$ \\
\hline Annual rainfall $(\mathrm{mm})$ & $\mathrm{I}, 487$ & $\mathrm{I}, 400$ \\
\hline Highest point $(\mathrm{m})$ & 875 & 430 \\
\hline $\begin{array}{l}\text { Temperature }(\text { average } \\
\left.\text { max. and min. }{ }^{\circ} \mathrm{C}\right)\end{array}$ & 22 and I7 & $\mathrm{II} .6$ and 5.8 \\
\hline Latitude & $31^{\circ} 33^{\prime} \mathrm{S}$ & $57^{\circ} 49^{\prime} \mathrm{N}$ (Hirta) \\
\hline
\end{tabular}



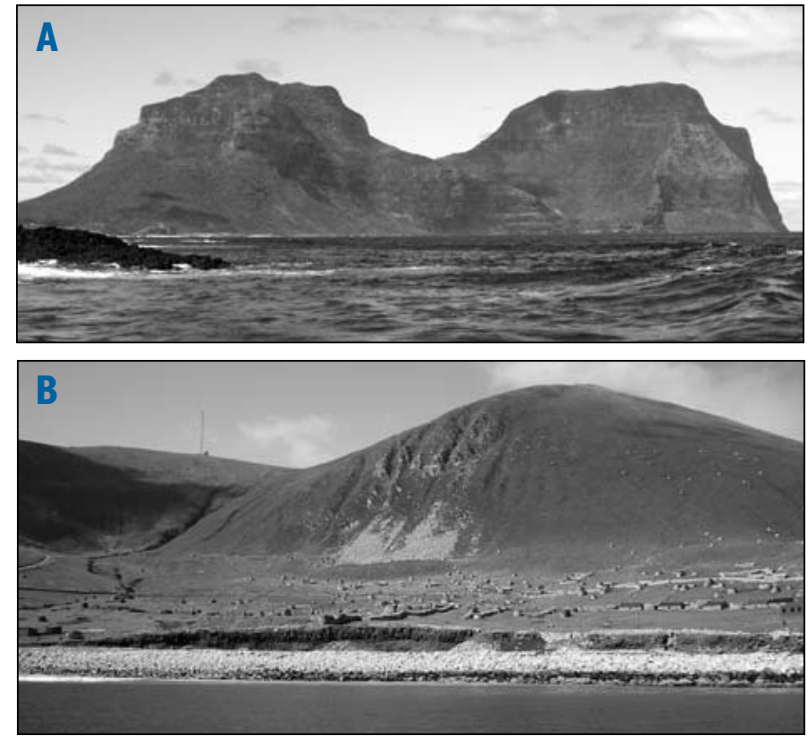

FIGURE 2 Lord Howe Island (A) and St Kilda (B) share many characteristics, including sheer cliffs, high rainfall and an abundance of bird life. (Author's own photographs.)

archaeological evidence of occupation 2,000 years ago and of Viking occupation a millennium ago, with some Viking names still retained today. Habitation is documented from the sixteenth century onwards, all of which makes continuous occupation for 2,000 years highly probable. When permanent residence was terminated 80 years ago, the island lacked even the most basic facilities; it did not have electricity, sewers or running water.

Lord Howe Island has no detectable trace of human habitation prior to 1788 in spite of the extensive exploratory maritime voyages of the Polynesian people. Its first known sighting was by the HMS Supply captain Lieutenant Henry Lidgbird Ball and his crew on 17 February 1788 while sailing to Norfolk Island. ${ }^{2}$ They subsequently landed there on I 3 March 1788 during the return journey to Sydney and named the island after Richard Howe, the First Lord of the Admiralty. (Howe coincidentally had a Scottish connection, having sustained a severe head wound during the Jacobite rising in 1745 while commanding the sloop HMS Baltimore.) Today, Lord Howe Island has 347 permanent residents.

\section{SOIL FERTILITY, NUTRITION AND DIET}

Both islands have volcanic origins, Lord Howe Island being 7,000 million years old and St Kilda being 60,000 million years old. Volcanic soil has the reputation of great fertility as it is a rich source of essential plant minerals, trace elements and other nutrients. Lord Howe Island, with an average annual rainfall of nearly $1,500 \mathrm{~mm}$ and a mean daily temperature around $19^{\circ} \mathrm{C}$, fits this pattern. Its soil supports lush subtropical vegetation and abundant food supply in the relatively flat larger part of the island to the north of the two large mountains (Figure 2A).
However, this theory of great fertility clearly did not apply to St Kilda, probably due to a combination of climatic and management factors. Firstly, the volcanic soil was largely scoured out by glacial action in the last ice age, leaving barren sub-arctic land. The 350-year period of recorded history describes a small area of arable land with thin top soil, limited fertility and poor drainage, where crops such as barley may well have been grown for millennia, with very variable but often poor yields. The slope of Village Bay down to the sea (Figure 2B) and heavy rainfall may have caused the progressive erosion of top soil.

The St Kildans were not known for their skilled land husbandry. They did not rotate crops or leave fallow areas, and their method of fertilising the land with peat ash and other refuse has recently been found to have contaminated the soil with dioxin and heavy metals. ${ }^{3}$ While there is no evidence that this caused human toxicity, it may well have further impaired soil fertility. As a result the St Kildans' diet, predominantly consisting of seabirds and their eggs, was poor in fruit and vegetables, making it probable that vitamin $C$ and other deficiencies may have contributed to their susceptibility to infection.

It has been suggested that vitamin $\mathrm{D}$ deficiency may also have contributed to the susceptibility to infection of communities such as St Kilda. ${ }^{4,5}$ Long dark Scottish winters are known to be associated with low vitamin D levels and Scotland is above the latitudes that receive adequate exposure to the ultraviolet $B$ wavelengths required for vitamin $D$ synthesis from October to April. ${ }^{5}$ However, the inhabitants of St Kilda should not have been subject to this problem as their diet contained some fish and was rich in seabirds and their eggs. Fulmar oil, one of the archipelago's medical panaceas, is known to be one of the richest sources of vitamin D. Bone diseases and fractures were not recorded; falls from the vertical cliffs were usually fatal.

The first doctor to write about Lord Howe Island was surgeon Arthur Bowes on the Lady Penrhyn who noted in his journal the ease of capturing birds for dinner. ${ }^{2}$ The island's first connection with medicine was the recording of the capture of large turtles weighing up to $70 \mathrm{~kg}$ each to treat scurvy in the colony in Botany Bay in the late eighteenth century. ${ }^{2}$ (The presence of ascorbic acid in animal tissue may seem counter-intuitive, but Rice found box turtles had neurological tissue levels of ascorbic acid 2-100 times greater than the levels in other mammals, perhaps as an essential cerebral antioxidant to prevent oxidative cellular damage on resumption of aerobic metabolism after an hypoxic dive. ${ }^{6}$ ) In subsequent years, before permanent settlement, passing whalers used the island to replenish their ships' food and water stores. They even left pigs behind to populate the land and provide further food for future visitors. 
The island's first residents were three men from $\mathrm{New}$ Zealand, Ashdown, Bishop and Chapman, with their Maori wives and two Maori boys, who arrived on the barque Caroline in 1833 or 1834 and resided at Hunter Bay, subsequently renamed the 'Old Settlement'. ${ }^{2}$ Ashdown and his partner Emma had four children between 1836 and 1840, the island's first births. ${ }^{7}$ Within a year they had cultivated an area to produce potatoes, carrots, maize, pumpkin and the root vegetable taro, the staple source of carbohydrate on the island following its introduction from southeast Asia. They even provided whalers with provisions. ${ }^{2}$ Assistant surgeon John Macdonald, visiting on HMS Herald between I85I and 1854, wrote that the richness of the soil can scarcely be surpassed'.

\section{INFECTIOUS DISEASES AND BIODIVERSITY}

The health problems of St Kilda have been extensively documented. ${ }^{3,8-10}$ Inclement weather, low herd immunity, poor diet with vitamin deficiency and limited biodiversity of histo-compatibility antigens have been postulated as predisposing factors. In 1727 an infection almost wiped out the entire population when 94 islanders died, leaving one adult and 26 children as survivors. ${ }^{8}$ Immediately before the outbreak, a party of three men and eight boys had been taken by boat to a nearby sea stack to collect gulls and gull eggs. The epidemic struck suddenly and spread rapidly. Within six days there were not four healthy men to row the boat and collect this party, who were able to survive nine months through an Atlantic winter eating fish and birds in an epic but little-known feat of endurance. Unfortunately, no clinical details of this devastating illness have been recorded for posterity. Smallpox has always been the postulated cause, but the rapid spread and predominance of children among the survivors is also compatible with chickenpox. ${ }^{8}$

Before the advent of steamships in the mid-nineteenth century, when visitors to St Kilda were infrequent, virtually the entire population succumbed to respiratory tract infections within a few days of a visit. The short incubation period, widespread contagion, repeated episodes within weeks and occasional deaths with documented lower respiratory infection suggest rhinovirus as the most likely cause. ${ }^{9}$ Neonatal tetanus was responsible for the deaths of up to two-thirds of infants and the failure to replenish the population with an adequate young workforce was to prove a factor in the eventual failure of the community. ${ }^{10}$ Migration from St Kilda was far from a guarantee of improved health since, because of the infrequent occurrence of common infections, those travelling had poor immunity. In 1852 no fewer than 36 of the islanders emigrated to Australia. Although they were among the youngest and fittest from the community, they suffered a $50 \%$ mortality on the sail to Melbourne, mainly from measles, and several of the young children died of tuberculosis shortly after the evacuation."
The inbred population of St Kilda, never greater than 200, was predominantly Morrisons and McDonalds at the time of the 1727 epidemic, and afterwards such repopulation as occurred was mainly from five families on neighbouring Hebridean islands, suggesting limited genetic diversity.

Most of Europe, with its vigorous east-west travel and exchange of culture and trade (and DNA), had a wide genetic biodiversity of histo-compatibility antigens, the genetic key to immunological defence against viruses. The situation of the St Kildans may well have been similar to the pre-Columbian North Americans who had 64 times less biodiversity than that of the Europeans, and succumbed to European viruses not previously encountered, resulting in a population decline from perhaps 100 million to a few million in 300 years. $^{8}$ Smallpox is incriminated as causing the death of $90 \%$ of non-immune indigenous Americans in the sixteenth and seventeenth centuries. ${ }^{8}$

In contrast, Lord Howe Island appears a paradise of good health and longevity. Regular visits by whalers in the early years of settlement would have helped to reduce isolation and perhaps improve the herd immunity. William Clarson, a visiting teacher, wrote in 1882 that 'sickness is almost unknown'. Information about the health of the residents for the period of about 50 years from the first settlement until island records began is dependent on oral family traditions rather than written records. However, a visit to the four island graveyards shows that most inhabitants born more than 100 years ago survived into their 80 s.

One of the early settlers, Nathan Chase Thompson, from Somerset, Massachusetts, in the USA, arrived in 1853 with two business partners, George Campbell and Jack Brian, and two women and a girl from the Gilbert Islands (now Kiribati). Thompson initially married Boranga, one of the women, but their only child died aged II years and Boranga died soon after. Thompson subsequently married the Gilbertese girl, Bokue, who was by then aged 24 . They had five children, two boys and three girls, whose descendants are an important part of today's island population. Thompson's death certificate records influenza as the cause of his death at the age of 72 in 1895. ${ }^{2}$ William Nichols was another early settler, in 1862. Ten years later he married Hannah Baker and they had 12 children, but the first six died in infancy. No further details are available of the causes of these deaths.

The earliest settlers on Lord Howe Island had widespread origins, coming from England, Portugal, America, South Africa, Micronesia, New Zealand and Australia, probably with a great biodiversity of histo-compatibility antigens creating more resistance to infections than that of the Hebridean people of St Kilda. Supporting evidence 
TABLE 2 Figures from the St Kilda Island and District Registers (incomplete 1840-56)

\begin{tabular}{|l|l|l|}
\hline Date & Live births & No of neonatal deaths \\
\hline $1830-39$ & 61 & 35 \\
\hline $1840-49$ & 5 & - \\
\hline $1850-59$ & 11 & 5 \\
\hline $1860-69$ & 29 & 20 \\
\hline $1870-79$ & 28 & 14 \\
\hline $1880-89$ & 27 & 14 \\
\hline $1890-99$ & 25 & 6 \\
\hline $1900-09$ & 15 & 2 \\
\hline $1910-19$ & 17 & 1 \\
\hline $1920-29$ & 7 & 0 \\
\hline
\end{tabular}

comes from an epidemic of measles, a disease with a mortality of up to $25 \%$ in the developing world. In I868, some inhabitants of the Pitcairn Islands visited Lord Howe Island in the schooner Pacific while suffering an outbreak of measles. They landed and recovered on the island, causing an inevitable outbreak of the disease among the islanders. ${ }^{7}$ No more details are available, but no deaths in 1868 are to be discovered in the island graveyards, implying that poor herd immunity allowed the outbreak of measles but the genetic and environmental background resulted in uneventful recovery. The most proximate death recorded on a gravestone is that of John Henry, who died on 4 February 1865 aged six and three months, although beside his grave are four small unmarked children's graves. John Henry died before the New South Wales (NSW) register began and there is no traceable death certificate, but his death was probably from trauma, resulting from a fall down the hull of his father's boat, Aladdin. ${ }^{13}$

The Lord Howe Island register of births, deaths and marriages commenced in 1880. Early causes of deaths were believed to be infections, particularly measles, whooping cough, pneumonia and, in the very young, febrile convulsions. Some infants died within a few hours or days of birth; for example, the son of John and Mary Robbins died seven days after birth, the classical time for neonatal tetanus. A review of the NSW registry of births and deaths from its inception and a search among the graveyards detected ten children who died by the age of 12 between 1865 and 1915 .

John Henry died of trauma before records began. Caroline and William Nichols and Juanita Retmock have a grave but do not appear in the births and deaths register. Recorded causes of death for the six children who have death certificates are as follows: Phillip Thompson - convulsions for one day, died aged seven days; Owen Payten - convulsions for two days, died aged ten days; Emmeline and Phyllis Dignam - whooping cough, followed by bronchitis; John Charles Thompson

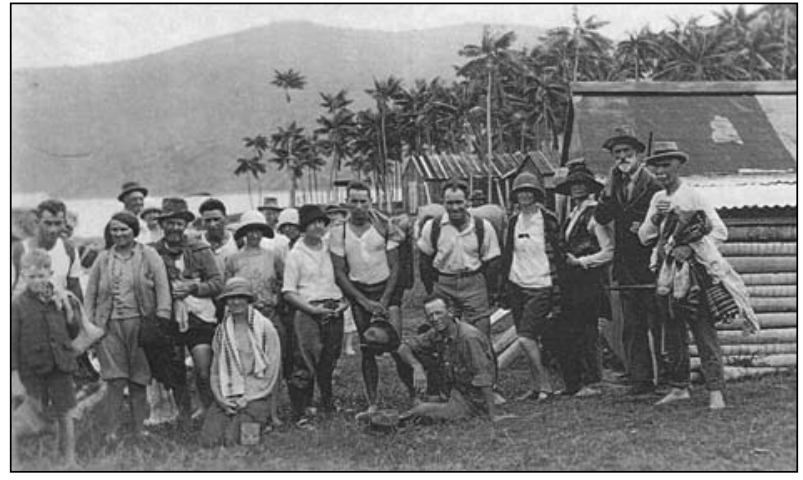

FIGURE 3 Early settlers at the Lord Howe Island seed shed. The men are carrying two-bushel bags of palm seed on their backs. The export of Kentia palm seeds is still one of the mainstays of the island's economy today. (With thanks to LHI Museum, www.lhimuseum.com)

- bronchitis, died aged 2 I days; William James Thompson - heart failure, died aged nine days. ${ }^{12}$ All their death certificates note that there was no medical attendant on the island.

\section{NEONATAL DEATHS AND MIDWIFERY}

Over a period of at least 150 years, infants on St Kilda frequently died within days of their birth having had spasms and convulsions. In some years the death rate exceeded $60 \%$ (Table 2). By 1890 this condition was recognised as neonatal tetanus. Deliveries on St Kilda were performed by untrained older women who would hold the position for many years before handing over to a successor, all of them seemingly unaware of the importance of maintaining sterility of the umbilical cord.

These births were never observed by men, nor anyone with medical training. For some 80 years the unsubstantiated theory that the application of fulmar oil to the umbilical cord caused the deadly infection held credence. ${ }^{10}$ However, recent bacteriological studies have confirmed the ubiquitous presence of Clostridium tetani in the island soil and tend to exclude infection from fulmar oil. ${ }^{14}$ The infection of the umbilical cord is much more likely to have come from the instrument used to sever the cord or from contaminated dressings. ${ }^{10}$ In 1906 a visiting doctor found a 'greasy and not overclean lancet', apparently 40 years old, still in use on the island for blood-letting. ${ }^{15}$ The advent of a trained midwife and the use of newer sterilisation measures in the final years of the nineteenth century saw the prevention of these neonatal deaths.

On Lord Howe Island in the nineteenth century obstetrics was performed by four of the island's women, all coincidentally called Mary. Their training came from TB Wilson, an island teacher with unknown medical training and one of the pioneers of the Kentia palm seed export business (Figure 3), which is still one of the mainstays of the island's economy today. His background 


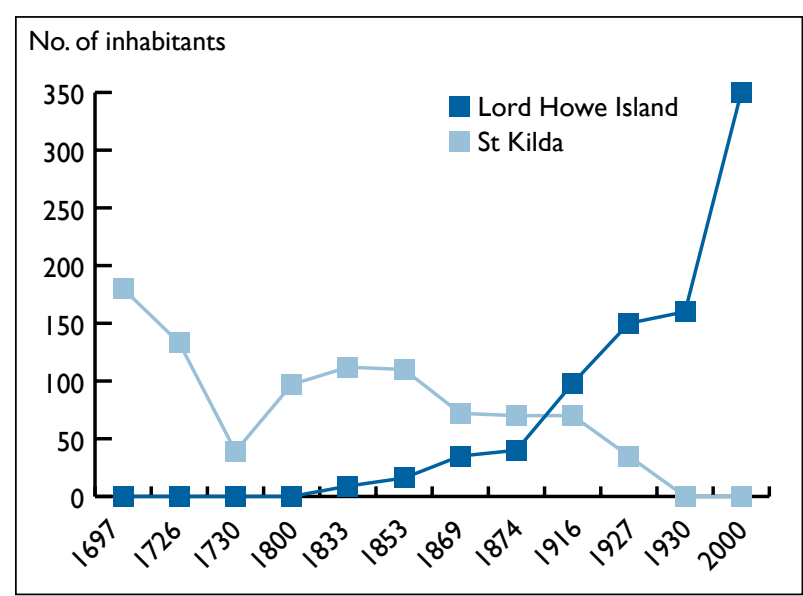

FIGURE 4 Populations on both islands, 1697-1930. was the British Army, and he also worked as a mine overseer before arriving on Lord Howe Island in 1878. His activities included medicine, writing poetry, preaching in church and gardening, but his considerable skills appeared untutored beyond his military experiences.

The deaths of Phillip Thompson, Owen Payten and John and Mary Robbins' son from convulsions at seven to ten days are strongly reminiscent of the deaths from neonatal tetanus on St Kilda, but other causes of death such as cerebral haemorrhage are usually more frequent in developed communities. The absence of any recorded maternal or other neonatal deaths, even with complex deliveries, implies the competence of teacher and pupils. Even if three children died of neonatal tetanus, perhaps from suboptimal management of the umbilical cord, the vast majority of babies survived. Mary Nicholls is recorded as turning a breech baby, after obtaining signed consent. ${ }^{16}$ The presence of four such successful midwives perhaps implies co-operative teamwork, peer review and sharing of ideas, the foundation of medical education today, in contrast to the risks implicit in inadequate handover, a possibility on St Kilda.

\section{DOCTORS}

St Kilda never had a resident doctor. A fulmar oil bottle or a bottle of whisky was commonly available for medicinal purposes. Doctors arrived occasionally to vaccinate the islanders, but generally medical visits were infrequent in the twentieth century. A trained midwife was introduced in 1890 but was initially made unwelcome by the residents. ${ }^{17}$ In 1930, just months before the island's evacuation, Mary Gillies died at the age of 21 , probably from appendicitis. Notification of her illness and her move to a hospital in Glasgow took two weeks and she died within 24 hours of admission. ${ }^{18}$

On Lord Howe Island, John Foulis, MD Edinburgh 1839 , resided with his wife and children from 1844 to 1848 . Two of their children, a daughter in 1844 and a son in
1845, were born on the island. Foulis, like the earlier settlers, worked as a merchant and little information is available on any medical practice he may have performed on the island. He introduced aloe and castor oil plants. ${ }^{7}$

Alfred T Corrie RN, a surgeon, visited in 1878 on HMS Pearl. He noted that the islanders appeared in good health but observed occasional rheumatism in the seafarers. Epsom salts appeared to be the panacea for all ills. During the 1882 inquiry into the island administration of Captain Armstrong, it was noted that a little colonial wine and brandy had become the standard remedy for all ills. ${ }^{7}$ This medicinal use of alcohol represented common practice in many other isolated communities. Following the inquiry, a medicine chest was provided by the NSW State Government for Lord Howe Island.

During the period from 1920 to the outbreak of the Second World War, the NSW government sent various doctors to Lord Howe Island, supposedly to recover from tuberculosis, although many seemed to be recovering from alcoholism. ${ }^{4} \mathrm{Dr}$ Deerberg may well have been suffering from tuberculosis as he carried a sputum container with him. Dr Thomas Brockhoff and Dr Mackay also worked on the island, providing services to the sick within their limits of expertise, equipment and facilities, including operations such as appendicectomy on the kitchen table with a penknife. ' Before the opening of the Lord Howe Island Hospital in 1941, an operation on the kitchen table was not an unusual event. The Lord Howe Hospital information board records that on one memorable occasion in 1938, a ship's doctor brought a table and set of surgical instruments ashore with him to perform an appendicectomy on a home visit.

\section{POPULATIONS}

The population of St Kilda fell drastically after the 1727 epidemic, yet recovered within a year or two with repopulation. It fell again in 1852 when a group of 36 migrated to Australia and then diminished progressively as contacts with the outside world increased after the First World War, until the population of 36-37 people became unsustainable and the island was evacuated in 1930. In contrast, the population of Lord Howe Island increased exponentially over 100 years (Figure 4) and is now capped at around 350 to protect the environment. A similar number of tourists are allowed each year.

\section{THE ROLE OF RELIGION}

The role of the Presbyterian church in the life of the Hebridean people remains controversial. Ministers were more knowledgeable, literate, educated and experienced in the outside world and were able to wield great power and influence over their flocks. ${ }^{18}$ St Kilda had a resident minister, or latterly missionary, almost continuously from 1705 to 1930. 
The lifestyle of the St Kildans, specifically the gathering of food, required the whole society to work together in organised roles daily from dawn to dusk. Some writers have suggested that the time taken by religious ceremony prevented the people of St Kilda from having adequate time to survive as hunter gatherers. ${ }^{17}$ Several observers perceived an effect on the happiness of the people and their ability to move on from crises, perhaps through some sort of wake, when the prevailing atmosphere induced by their religion was of misery and depression at their state of sinfulness. Music, non-religious singing, dancing and laughter had all been banned. ${ }^{18}$ In 1697 , before the arrival of resident ministers, Martin recorded that 'the inhabitants of St Kilda, are much happier than the generality of mankind', ${ }^{19}$ yet by 1822 'the St Kildans lost their sense of gaiety and their love of song and dance', according to Steel. ${ }^{17}$ These introduced customs may have played a role in the decline of a previously viable and happy society.

In contrast, music was an important part of social interactions on Lord Howe Island, starting with Allan Mosely, a former whaler, who entertained visiting ships' crews with his flute and Irish jigs. Missionaries initially visited Lord Howe Island intermittently. In the early twentieth century, Anglican, Seventh Day Adventist and Catholic churches opened, offering a choice of denomination, rather than a rigid monopoly. Religion and church music were important to the islanders but did not dominate all aspects of life nor ban pleasure during the week. Parties, dances, sports, events such as house warmings, the school opening and the arrival of tourism shaped the way of life on Lord Howe Island in the second half of the nineteenth century and probably contributed to the cohesive attitude of the inhabitants. ${ }^{20}$

The climatic differences may have played a psychological role in the viability of the two societies. Seasonal affective disorder may have contributed to the terminal malaise afflicting the occupants of St Kilda, where cold grey skies, rain and storm were the norm. On the other hand, it is hard to feel unhappy under the predominant blue sky and warm breezes of Lord Howe Island.

\section{CONCLUSION}

The two islands have many medical and other characteristics in common, in particular low herd immunity from isolation and susceptibility to infection; yet only one of them thrives today. Medical factors played a major role in the success of Lord Howe Island and the failure of St Kilda. Appendicitis became a manageable problem on Lord Howe Island but was a final straw leading to the evacuation of St Kilda. The climate and virgin soil allowed the Pacific islanders a much more beneficial varied diet with food rich in vitamin $C$. This fact plus the biodiversity of the early settlers and their improved obstetric care protected the young children of Lord Howe Island from infections and guaranteed the survival of the Pacific island society.

\section{REFERENCES}

I Phillipps P. The flying boat days: the early aviation history of Lord Howe Island. Henley Beach, South Australia: Seaview Press; 2002.

2 Rabone H. Lord Howe Island: its discovery and early associations, I 788 to I888. Sydney: Australis Publications; 1972.

3 Stride P. Dioxin, diet and disease on St Kilda. J $R$ Coll Physicians Edinb 2009; 39:370-4. doi: I0.4997/JRCPE.2009.4I7

4 Adams JS, Ren S, Liu PT et al. Vitamin D-directed rheostatic regulation of monocyte antibacterial responses. J Immunol 2009; I82:4289-95. doi:I0.4049/jimmunol.0803736

5 Pearce SH, Cheetham TD. Diagnosis and management of vitamin D deficiency. BMJ 2010; 340:b5664. doi:I0.II36/bmj.b5664

6 Rice ME, Lee EJ, Choy Y. High levels of ascorbic acid, not glutathione, in the CNS of anoxia-tolerant reptiles contrasted with levels in anoxia-intolerant species. J Neurochem 1995; 64:1790-9. doi:10.1046/j.|47|-4I59.1995.6404I790.x

7 Nichols D. Lord Howe Island rising. Brookvale, NSW: BA Printing \& Publishing Services; 2006.

8 Stride P.The St Kilda epidemic of 1727, smallpox or chickenpox? J R Coll Physicians Edinb 2009; 39:276-9.

9 Stride P.The St Kilda boat cough under the microscope. J R Coll Physicians Edinb 2008; 38:250-60.

10 Stride P. St Kilda, the neonatal tetanus tragedy of the nineteenth century and some twenty-first century answers.J R Coll Physicians Edinb 2008; 38:70-7.

II Holohan AM. St Kilda: emigrants and disease. Scott Med J 1986; 31:46-49.

12 NSW Register of Births, Deaths and Marriages. Available from: http://www.bdm.nsw.gov.au/familyHistory/familyHistory.htm

13 Personal communication, Sandi Beaumont (great-great-granddaughter of Nathan Thompson) and Thelma Thompson (niece of John Charles Thompson), Lord Howe Island Museum; 2010.

14 Poxton IR. The islands of St Kilda and the 8-day sickness. Edinburgh: University of Edinburgh; 2010. Available from: http://www.wales. nhs.uk/sites3/Documents/882/lan\%20Poxton.pdt

15 Robson M. St Kilda Church, visitors and 'natives'. Port of Ness, Lewis: Islands Book Trust; 2005.

16 McFadyen K. Pinetrees, Lord Howe Island 1842-1992: a brief history of the Andrews-Nichols-Kirby families. Lord Howe Island, NSW: Pinetrees Publishing; 1992.

17 Steel T. The life and death of St Kilda. 2nd ed. London: Harper Collins; 1994.

I8 Maclean C. Island on the edge of the world: the story of St Kilda. Edinburgh: Canongate; 2006.

19 Martin M. A description of the Western islands of Scotland. London: Andrew Bell; 1703. Available from: http://www.undiscovered Scotland.co.uk/usebooks/martin-westernislands/index.html

20 Hayward P. Hearing the call: music and social history on Lord Howe Island. Lord Howe Island, NSW: Lord Howe Island Arts Council; 2002 